\section{DIARY}

100th FDI Annual World

Dental Congress

Date: 29 August - 1 September 2012

Location: Hong Kong

www.fdicongress.org

Oral health inequalities

- national and international

Date: 8 September 2012

Venue: Royal Society of Medicine

www.rsm.ac.uk/academ/odc08.php

\section{PER/IADR Congress}

Date: 12-15 September 2012

Location: Helsinki, Finland

http://iadr.com/i4a/pages/index.

cfm?pageid $=3955$

ITI Congress Finland:

When surgery meets prosthetics

Date: 14-15 September 2012

Location: Helsinki

Email: events@iticenter.ch

www.iti.org/congressfinland

\section{Optimising Outcomes}

in Restorative Dentistry

Date: 20 September 2012

Venue: Symposium Hall of the College,

The Royal College of Surgeons

of Edinburgh

Email:h.anderson@rcsed.ac.uk

Telephone: 01316689239

https://ubis.rcsed.ac.uk/courses/

coursedetails.aspx?diaryld=1027

\section{DDU-Eastman}

Dento-Legal Conference

Date: 28 September 2012

Location: London

Email:edi-cpd@ucl.ac.uk

www.the-ddu.com

ITI Congress Greece: Implants in daily practice: today and tomorrow Date: 29-30 September 2012

Location: Athens

Email: events@iticenter.ch

www.iti.org/congressgreece

BDTA Dental Showcase

Date: 4-6 October 2012

Venue: ExCeL London

www.dentalshowcase.com

BSDHT Oral Health Conference

and Exhibition

Date: 9-10 November 2012

Venue: ACC, Liverpool

Telephone: 01452886365

www.bsdht.org.uk

\title{
IS SEAWEED SUPERIOR TO TOOTHPASTE?
}

A team of dentists and scientists from Newcastle University are developing a new product from seaweed to protect dentures, teeth and gums from bacteria in the mouth.

The team are using an enzyme isolated from the marine bacterium Bacillus licheniformis found on the surface of seaweed which they were originally researching for the purpose of cleaning the hulls of ships.

Speaking at the Society for Applied Microbiology summer conference in July, the researchers explained how they are beginning to realise the bacterium's potential in a host of medical environments - including teeth cleaning.
Dr Nicholas Jakubovics of Newcastle's School of Dental Sciences believes that products for the mouth offering longer and more effective protection than toothpaste can be made from the enzyme.

'Work in a test tube has shown that this enzyme can cut through the plaque or layer of bacteria and we want to harness this power into a paste, mouthwash or denture cleaning solution,' said Dr Jakubovics.

The enzyme from the marine bacterium breaks up and removes the bacteria present in plaque and can also prevent the build up of plaque.

'This is just one of the uses we are developing for the enzyme as it has huge potential such as in helping keep clean medical implants such as artificial hips and speech valves which also suffer from biofilm infection,' said Professor Grant Burgess, who is leading the research team.

The team's next step is to further test and develop the product and they are looking to set up collaboration with industry.

\section{HOMININ TEETH REVEAL DIET OF BARK AND LEAVES}

Analysis of teeth dating back two million years suggests certain early relatives of humans had a unique diet of bark and harder vegetation, a discovery not seen before in other hominid species.

A recent study published in Nature by Henry et $a l .{ }^{1}$ examining dental calculus and microwear has revealed that Australopithecus sediba, early hominids from South Africa, lived on a varied diet that included tree leaves and bark. Phytoliths (plant-produced silica bodies) were found trapped in the dental calculus, presenting a record of the plant foods consumed by the specimen. From two extracted teeth, 38 phytoliths were recovered, signifying a mixed diet of fruit, leaves and uncommonly for African hominin, bark and woody tissues. Their dietary ecology does resemble many primates, however, such as the savanna chimpanzee.

Dental microwear texture analysis indicates the $A u$. sediba consumed much rougher foods than the Homo habilis and other early relatives, providing evidence that suggests they were facultative tree climbers, accessing the nutrients from higher plant life when fruit resources were low. The study supports hypotheses that human ancestors explored a wide range of habitats, spreading from Africa across the world before the evolution of Homo erectus.

1. Henry A G, Ungar PS, Passey B H et al. The diet of Australopithecus sediba. Nature 2012; 487: 90-93.

By Laura Pacey

\section{LONDON 2013: SAVE THE DATE}

\section{DENTAL \\ CONFERENCE \&EXHIBITION}

After three years in the North West of England, the 2013 British Dental Conference and Exhibition will be held at ExCel London, on 25-27 April.

Building on this year's highly successful event in Manchester, where there were a record number of attendees, the 2013 event will offer delegates the opportunity to keep up to speed with developments in dentistry; learn from some of the best speakers in the industry; sample new products; network with peers; share knowledge and experience; meet new career challenges; and of course socialise.

You can follow the build-up to the event on Facebook: www. facebook.com/bdaconference and Twitter: @BDAConference.

Booking opens this autumn. 